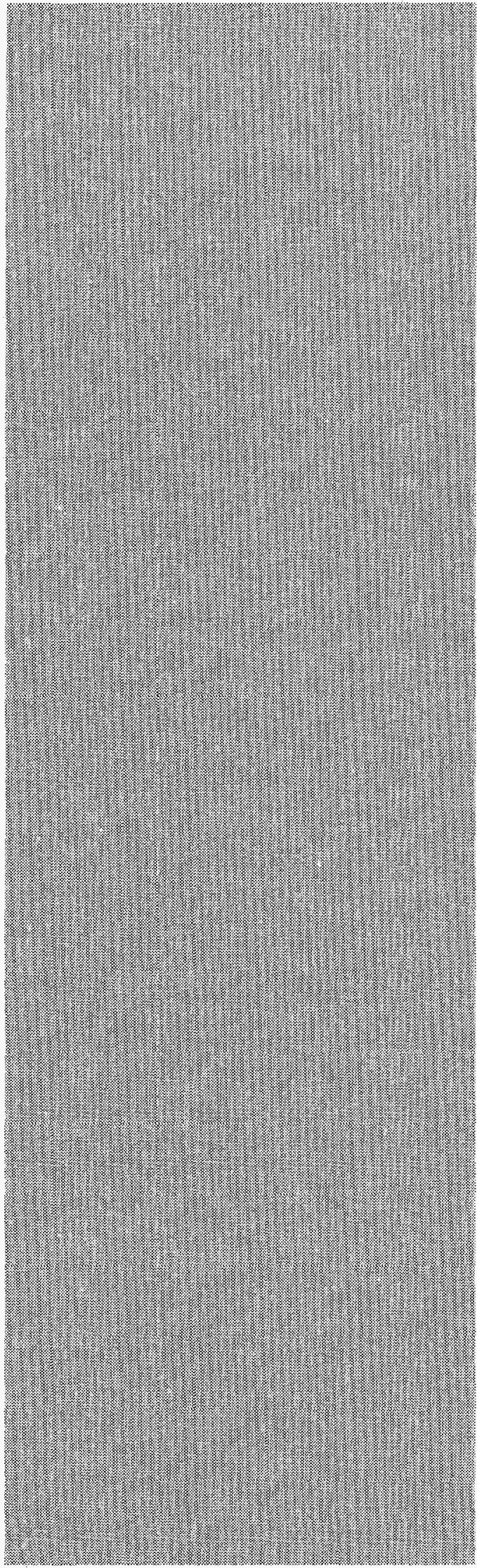

\title{
An Analysis of Background Noise in \\ Selected Canyons of Los Alamos County
}

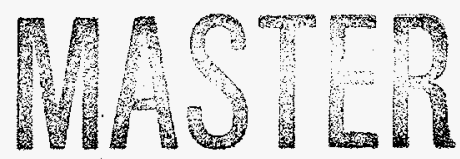

\section{Los Alamos}

Los Alamos National Laboratory is operated by the University of California for the United States Department of Energy under contract W-7405-ENG-36. 
Edited by Hector Hinojosa, Group CIC-1

An Affirmative Action/Equal Opportunity Employer

This report was prepared as an account of work sponsored by an agency of the United States Government. Neither The Regents of the University of Califormia, the United States

Government nor any agency thereof, nor any of their employees, makes any warranty, express or implied, or assumes any legal liability or responsibility for the accuracy, completeness, or usefulness of any information, apparatus, product, or process disclosed, or represents that its use would not infringe privately owned rights. Reference herein to any specific commercial product, process, or seroice by trade name, trademark, manufacturer, or otherwise, does not necessarily constitute or imply its endorsement, recommendation, or favoring by The Regents of the University of California, the United States Government, or any agency thereof. The views and opinions of authors expressed herein do not necessarily state or reflect those of The Regents of the University of California, the United States Government, or any agency thereof. Los Alamos National Laboratory strongly supports academic freedom and a researcher's right to publish; as an institution, however, the Laboratory does not endorse the viewoint of a publication or guarantee its technical correctness. 
An Analysis of Background Noise in Selected Canyons of Los Alamos County

Kristin Huchton

Steven W. Koch

Rhonda Robinson

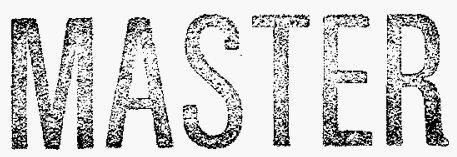




\section{DISCLAMMER}

Portions of this docament may be illegible in electronic image products. Images are produced from the best available original docoment. 


\section{CONTENTS}

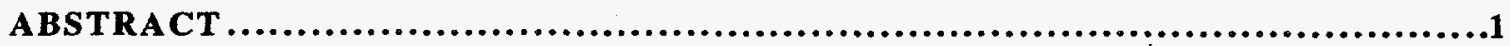

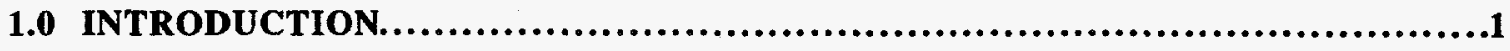

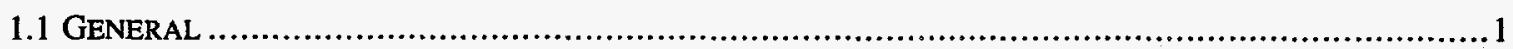

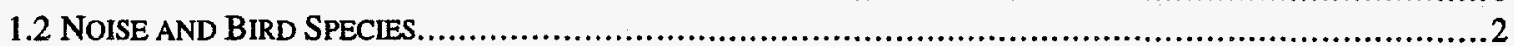

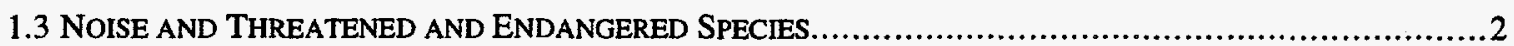

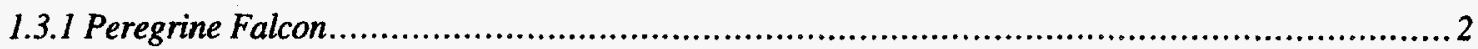

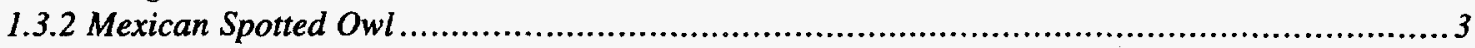

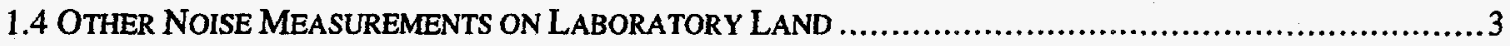

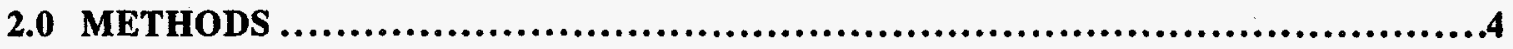

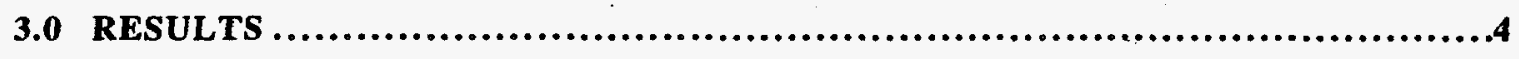

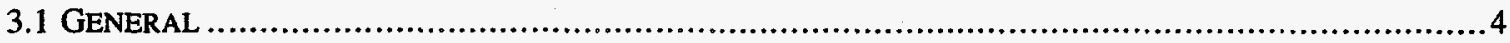

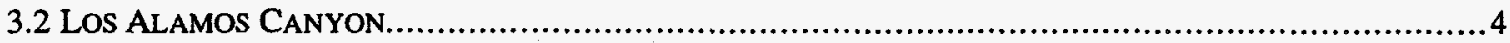

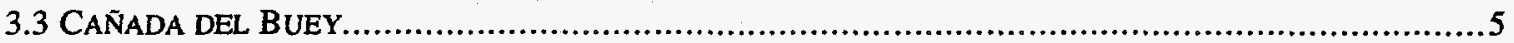

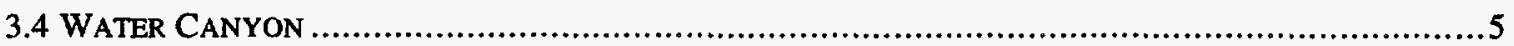

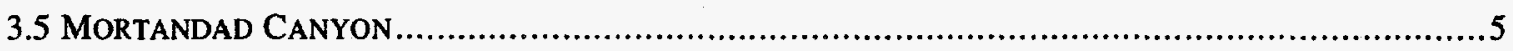

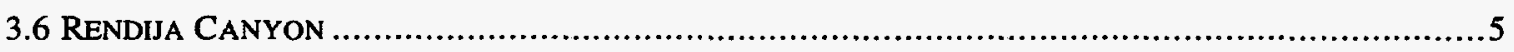

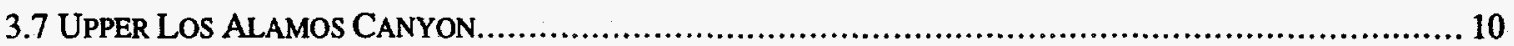

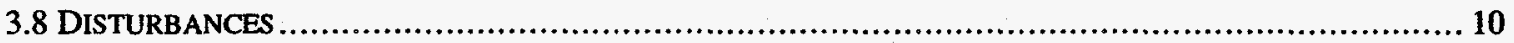

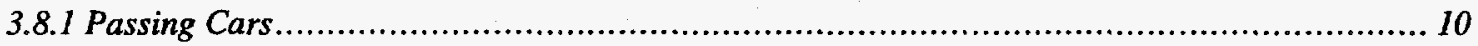

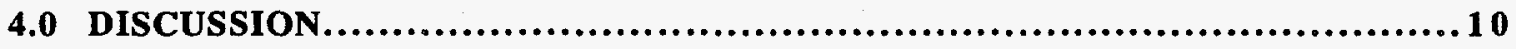

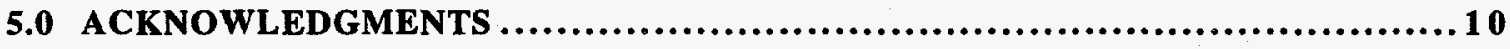

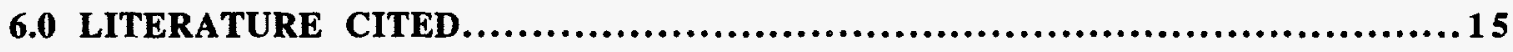

\section{LIST OF FIGURES}

Figure 1. Sound levels recorded at each one-mile mark in Los Alamos Canyon. ..................6

Figure 2. Sound levels recorded at each one-mile mark in Cañada del Buey.......................8

Figure 3. Sound levels recorded at each one-mile mark in Water Canyon.............................9

Figure 4. Sound levels recorded at each one-mile mark in Mortandad Canyon......................11

Figure 5. Sound levels recorded at each one-mile mark in Rendija Canyon..........................12

Figure 6. Sound levels recorded at each one-mile mark in Upper Los Alamos Canyon.........13

Figure 7. The data points recorded at the gates of Los Alamos Canyon (Series 1), Cañada del Buey (Series 2), and Water Canyon (Series 3) during the three-minute period when cars passed by.

\section{LIST OF TABLES}

Table 1. Measurements taken in Los Alamos Canyon; August 6, 1997, 8:30 to 9:30 AM. .5 Table 2. Measurements taken in Cañada del Buey; August 6, 1997, 9:55 to 10:40 AM. .....7

Table 3. Measurements taken in Water Canyon; August 20, 1997, 9:00 to 9:45 AM........7 
Table 4. Measurements taken in Mortandad Canyon; August 25, 1997, 1:40 to 2:25 PM. .7

Table 5. Measurements taken in Rendija Canyon; August 25, 1997, 3:35 to 4:05 PM. .......13

Table 6. Measurements taken in Upper Los Alamos Canyon; August 25, 1997, 4:29 to 4:45 PM..

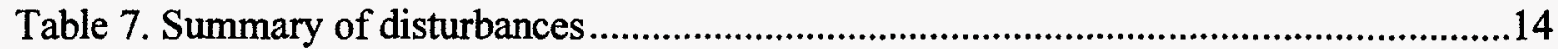

Table 8. Noise levels of passing cars at the gates of three canyons.....................................14 


\title{
An Analysis of Background Noise in Selected Canyons of Los Alamos County
}

\author{
by
}

Kristin Huchton, Steven W. Koch, Rhonda Robinson

\begin{abstract}
We recorded background noise levels in six canyons within Los Alamos County in order to establish a baseline for future comparisons and to discover what noises animals are exposed to. Noise level measurements were taken within each canyon, beginning at an established starting point and at one-mile intervals up to four miles. The primary source of noise above $55 \mathrm{dBA}$ was vehicular traffic. One clap of thunder provided the highest recorded noise level ( $76 \mathrm{dBA})$. In general, the level of noise, once away from highways and parking lots, was well below $60 \mathrm{dBA}$.
\end{abstract}

\subsection{Introduction}

\subsection{General}

Since wildlife is influenced in some way when humans enter their habitats, we must examine the impact that our activities have on survival, especially on threatened or endangered species. Whenever a project is initiated, there are many changes that take place in the area, one of which is the introduction of additional noise. The effects of noise have often been studied from a human health perspective but have not been extensively studied for influences to other species. The limited studies made concerning noise disturbance and animals indicate that noise may affect the behavior of some species (Ellis et al. 1991, Awbrey and Hunsaker 1997, Delaney et al. 1997). This study provides baseline data for background noise levels in six canyons in Los Alamos County. The analysis of existing noise levels will allow for better evaluation of future project impacts.

Noise is defined as unwanted sound. Sound is a form of energy that travels as invisible pressure vibrations in various media, such as air. Sound pressure level is usually measured in decibels (dB), a logarithmic scale. Sounds that people (and birds) can hear are given more weight than sounds that cannot be heard. The so-called A-weighted response (dBA) closely imitates the response of the human ear by filtering out the lower and higher frequencies not normally heard by the human ear. Studies examining the effects of noise on birds (and people) typically use the Aweighted curve. 
Environmental noise exposure is measured outdoors. The sound levels vary and depend on the generator. The following are typical examples of sound levels (dBA) generated by barking dogs (58), sports events (74), local cars (63), aircraft overhead (66), children playing (65), and birds chirping (54) (Bell et al. 1982).

\subsection{Noise and Bird Species}

There are several ways that noise could adversely affect birds: (1) by masking calls, (2) by initiating a flight response, or (3) by causing a physiological effect. The masking of vocalizations could impact the establishment and defense of territories and the attraction and maintenance of mates, causing a decline in successful reproduction (RECON 1997). Noise may also cause a nest to be abandoned, an interruption in the care of young, physiological stress of adults or young, premature fledging, and the loss of eggs or small chicks that are kicked from the nest by startled adults (Ellis et al. 1991).

However, numerous studies have failed to show a strong correlation between noise levels and reproductive rate (Ellis et al. 1991, Awbrey et al. 1995, Awbrey and Hunsaker 1997, Fletcher and Busnel 1978). Ellis et al. (1991) experimented with the effects of low-level jet aircraft and mid- to highaltitude sonic booms on raptors. They found that $95 \%$ of the nests that were subjected to the stimuli successfully fledged young, and $95 \%$ were reoccupied the following year. In another study involving California gnatcatchers (Polioptila californica), noise from aircraft poorly correlated with reproductive success or failure, and if "noise does have an effect, ... . it is overwhelmed by such factors as predation, weather, edge effects, and differences in quality of habitat" (Awbrey and Hunsaker 1997).

Noise, such as that from lowflying aircraft and sonic booms, has been shown to disturb birds, with the severity of the disturbance varying from insignificant (interrupting an activity such as preening) to a flight response. Excessive flight response may be harmful to the birds because food intake may be lowered while the expenditure of energy is increased (Ward et al. 1994). Sonic booms have also been circumstantially associated with the $99 \%$ reproductive failure of Dry Tortugas sooty terns (Terna fuscata) (Fletcher et al. 1978).

Another concern is whether or not the sound level is the determining factor in response behavior, Delaney et al. (1997) noted that the distance of a helicopter was a better predictor of response than was sound level. They also commented that chain saws, although not as loud or as close as helicopters, had a higher frequency of flush responses.

1.3 Noise and Threatened and Endangered Species

A few studies have concentrated upon the effects of noise on specific threatened or endangered bird species in order to improve management practices.

\subsubsection{Peregrine Falcon}

Ellis et al. (1991) studied the effects of low-level military aircraft and mid- to high-altitude sonic booms on the 
peregrine falcon (Falco peregrinus). They found that noise was not a serious concern as 10 of the 12 nests that were subjected to the noise stimulus successfully fledged young. Reoccupancy was also within expected rates for a self-sustaining population.

\subsubsection{Mexican Spotted Owl}

Extensive research was carried out on the reaction of the Mexican spotted owl (Strix occidentalis lucida) during the nesting season to both helicopter overflights and chain saws (Delaney et al. 1997). It was found that flush response became more frequent as the distance to the disturbance decreased or when the sound level was raised. Interestingly, even though the chain saws were not as loud as the helicopters, owls responded from further away and with greater frequency than from helicopters. In regards to reproductive success, the findings indicated that aircraft overflights alone had a negligible effect.

\subsection{Other Noise Measurements on} Laboratory Land

Several sets of noise measurements have been taken in Los Alamos County.

During PHERMEX tests the background noise level was reported at 31 to $35 \mathrm{dBA}$ with peaks reaching 71.1 dBA from readings taken three-quarters of a mile east of the Technical Area (TA) 49 gate and $60 \mathrm{dBA}$ from readings taken 100 yards west of the Bandelier National Monument entrance (Vigil 1995) (Appendix 1). Measurements taken in White Rock during the same PHERMEX tests (Burns 1995) show a background noise ranging from $31 \mathrm{dBA}$ to $51 \mathrm{dBA}$ (caused by a passing car) and peak noise levels ranging from $60.9 \mathrm{dBA}$ (from a high-explosive load of $10 \mathrm{lb}$ of TNT) to $71.6 \mathrm{dBA}$ (from a high-explosive load of $100 \mathrm{lb}$ of TNT) (Appendix 2).

Sound levels were measured during an M-60 automatic rifle test (Macdonell 1984). One and two rifles were fired at four different locations while measurements were taken at five points. Background measurements ranged from 34 to $63 \mathrm{dBA}$, with measurements during firing ranging from 44 to $70 \mathrm{dBA}$ (Appendix 3).

Sound level measurements were also taken within Los Alamos Canyon to analyze the possible impact of noise within potential nesting habitat (Keller and Foxx 1997). Noise levels were measured from three different transects. First, background noise was measured in three locations: a mesa top, the bottom of the canyon, and at the base of the cliff containing the potential nest site; second, the noise from a truck horn on the TA21 mesa top was measured (Appendix 4); and third, the noise of the truck horn was measured from the north rim of the canyon, following a transect that led to the cliff on the north-facing slope containing the potential nest site, down into the canyon, and up the other side (Appendix 4).

Sound levels were also measured by Haarmann et al. (1997) in a wooded lot at TA-62 and in upper Los Alamos Canyon. They found that background noise levels in an area north of West Jemez Road and west of West Road averaged $72 \mathrm{dBC}$. Background noise levels in Los Alamos Canyon just north of this spot averaged $62 \mathrm{dBC}$. A car horn in this wooded area $(113 \mathrm{dBC})$ produced 
the sound levels reported in Appendix 5. These levels were measured at increasing 50-m (164-ft) points along a transect moving away from the source of the noise.

\subsection{Methods}

For this study, an Extech Instruments 401135 Sound Level Meter was attached to a six-foot-tall tripod. This allowed the sound level meter to be placed a minimum of six feet from any large solid surface, thereby avoiding the complications of reflected sound waves. The "low" range of the sound level meter-35 to $100 \mathrm{~dB}$-was used. The response time of the sound level meter was set to "slow." The A-weighting network, which responds to sound frequencies in a manner similar to human and avian hearing, was chosen in order to allow for comparison to existing data. A windscreen covered the microphone in order to reduce wind-generated noise. Before and after each measurement was taken, the sound level meter was internally calibrated.

Measurements were taken in six canyons: Los Alamos Canyon, Water Canyon, Cañada del Buey, Mortandad Canyon, Rendija Canyon and Upper Los Alamos Canyon. In Los Alamos Canyon, Cañada del Buey, Water Canyon, and Upper Los Alamos Canyon, measurements began at the gate and were taken every mile. The odometer of the vehicle was used to measure the distance between points. In Mortandad Canyon and Rendija Canyon measurements began at the end of the pavement and were taken every mile. At each mile mark, measurements were taken for three minutes, during which time the recorder took data about every three seconds, yielding approximately 110 points of data.

The data were analyzed and plotted with the program Microsoft Excel $^{\circledR}$. The mean, maximum, and minimum were determined, and the standard deviation was calculated.

\subsection{Results}

\subsection{General}

The primary sources of noise exceeding $55 \mathrm{dBA}$ were cars and trucks. Thunder provided the highest reading taken ( $76 \mathrm{dBA}$ ), but was only heard distinctly at one point. Generally, the sources of noise were environmental, such as the wind in the trees, the buzzing of bees, the calls of birds, and flowing water. Readings taken near flowing water were up to $11 \mathrm{dBA}$ higher than those readings taken away from the water in the same canyon. Human-generated noise included the hum of machinery and the sounds of joggers. In general the level of noise, once away from highways and parking lots, was well beneath $60 \mathrm{dBA}$.

Since the sound level meter could only measure levels above $35 \mathrm{dBA}$, it is possible that some of the canyons were quieter than what we recorded, in particular Mortandad Canyon, Water Canyon, and Rendija Canyon.

\subsection{Los Alamos Canyon}

Table 1 shows the noise level at the starting point and at one-mile intervals up to the fourth mile. Figure 1 shows the approximately 110 data points taken at each one-mile mark. The average at the gate was high because the gate is adjacent to State Road 4 and cars were passing almost continuously. 
Sources for noise in Los Alamos Canyon were environmental-a slight wind in the trees, the calling of birds, and a stream, which, at three miles from the gate, was approximately 25 feet away from the sound level meter and, at four miles from the gate, was less than 10 feet from the sound level meter.

\subsection{Cañada del Buey}

Table 2 shows the readings at the starting point and at one-mile intervals up to the third mile in Cañada del Buey. Figure 2 shows the approximately 110 data points taken at each one-mile mark. At the gate the higher levels were caused by the frequent passing of cars. Other sources of noise for Cañada del Buey were environmental and the hum of machinery at TA-54.

\subsection{Water Canyon}

Table 3 shows the readings at the starting point and at one-mile intervals up to the third mile in Water Canyon. Figure 3 shows the approximately 110 data points taken at each one-mile mark. Passing cars were heard periodically at the gate of Water Canyon, resulting in a higher maximum and overall mean. At the other points, noise was purely environmental.

\subsection{Mortandad Canyon}

Table 4 shows the measurements from Mortandad Canyon. Figure 4 shows the approximately 110 data points taken at each one-mile mark. The end of the pavement was located next to a parking lot, yielding the sound of one car pulling out and that of people walking from their cars to nearby buildings. The primary noises heard at the other points were environmental. Thunder was heard while measurements were made. One very loud clap of thunder was recorded four miles from the end of the pavement, giving the highest decibel reading taken in the study, $76 \mathrm{dBA}$.

\subsection{Rendija Canyon}

Rendija Canyon, Table 5, was the quietest canyon measured, and the actual levels could have been lower than the meter's lower limit of $35 \mathrm{dBA}$, which was recorded at three of the four points. There was no man-made noise audible while measurements were being taken.

\begin{tabular}{cc|cccc}
\hline \multicolumn{5}{c|}{ Table 1: Measurements taken in Los Alamos Canyon; August 6, 1997, 8:30 to 9:30 AM. } \\
\hline \hline & at gate & \multicolumn{4}{c}{ miles from gate } \\
\hline & $\varnothing$ & 1 & 2 & 3 & 4 \\
\hline mean (dBA) & 62 & 39 & 38 & 44 & 50 \\
\hline $\begin{array}{c}\text { maximum } \\
(\mathrm{dBA})\end{array}$ & 74 & 42 & 44 & 48 & 52 \\
\hline $\begin{array}{c}\text { minimum } \\
(\mathrm{dBA})\end{array}$ & 45 & 38 & 38 & 38 & 49 \\
\hline $\begin{array}{c}\text { standard } \\
\text { deviation }\end{array}$ & 6.1 & 1.1 & 1.0 & 1.0 & 0.7 \\
\hline
\end{tabular}




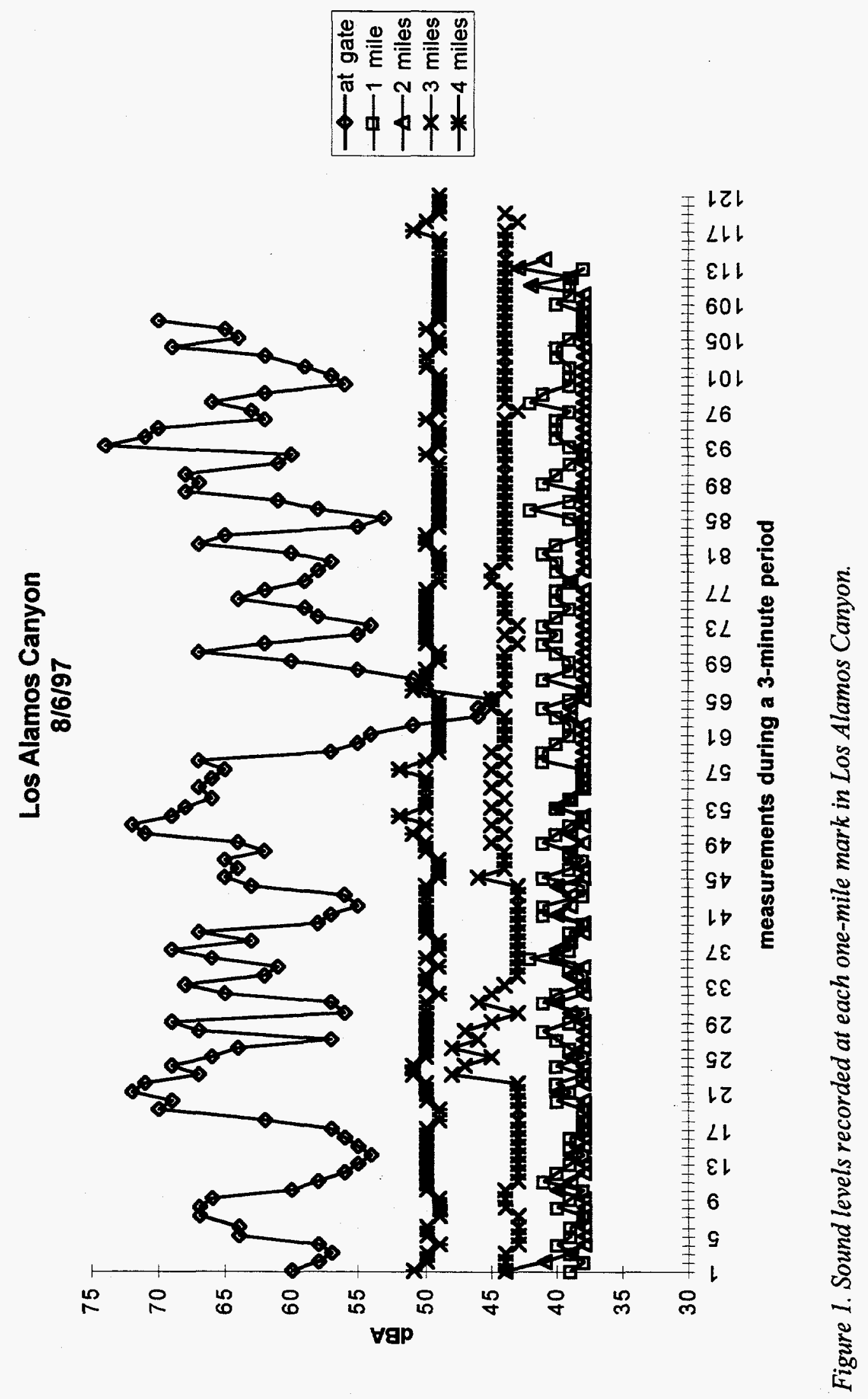




\begin{tabular}{cc|ccc}
\hline \hline \multicolumn{3}{c}{ Table 2: Measurements taken in Cañada del Buey; August 6, 1997, 9:55 to 10:40 AM. } \\
\hline \hline & at gate & \multicolumn{3}{c}{ miles from gate } \\
\hline & $\varnothing$ & 1 & 2 & 3 \\
\hline mean (dBA) & 47 & 44 & 37 & 37 \\
\hline $\begin{array}{c}\text { maximum } \\
(\mathrm{dBA})\end{array}$ & 63 & 48 & 39 & 38 \\
\hline $\begin{array}{c}\text { minimum } \\
\text { (dBA) }\end{array}$ & 38 & 40 & 37 & 37 \\
\hline $\begin{array}{c}\text { standard } \\
\text { deviation }\end{array}$ & 8.0 & 2.4 & 0.3 & 0.4 \\
\hline
\end{tabular}

\begin{tabular}{cc|ccc}
\hline \hline \multicolumn{4}{c}{ Table 3: Measurements taken in Water Canyon; August 20, 1997, 9:00 to 9:45 AM. } \\
\hline \hline & at gate & \multicolumn{3}{c}{ miles from gate } \\
\hline & $\varnothing$ & 1 & 2 & 3 \\
\hline mean (dBA) & 40 & 35 & 37 & 38 \\
\hline $\begin{array}{c}\text { maximum } \\
(\mathrm{dBA})\end{array}$ & 62 & 38 & 44 & 51 \\
\hline $\begin{array}{c}\text { minimum } \\
\text { (dBA) }\end{array}$ & 35 & 35 & 35 & 35 \\
\hline $\begin{array}{c}\text { standard } \\
\text { deviation }\end{array}$ & 7.6 & 0.4 & 2.1 & 4.3 \\
\hline
\end{tabular}

\begin{tabular}{cc|cccc}
\hline \hline \multicolumn{2}{l|}{ Table 4: Measurements taken in Mortandad Canyon; August 25, 1997, 1:40 to 2:25 PM. } \\
\hline \hline & $\begin{array}{c}\text { end of } \\
\text { pavement }\end{array}$ & \multicolumn{4}{c}{ miles from end of pavement } \\
\hline & $\varnothing$ & 1 & 2 & 3 & 4 \\
\hline mean (dBA) & 47 & 38 & 42 & 37 & 41 \\
\hline $\begin{array}{c}\text { maximum } \\
(\text { dBA })\end{array}$ & 61 & 445 & 58 & 51 & 76 \\
\hline $\begin{array}{c}\text { minimum } \\
(\text { dBA })\end{array}$ & 40 & 36 & 36 & 35 & 35 \\
\hline $\begin{array}{c}\text { standard } \\
\text { deviation }\end{array}$ & 4.7 & 2.0 & 4.9 & 2.9 & 8.8 \\
\hline
\end{tabular}




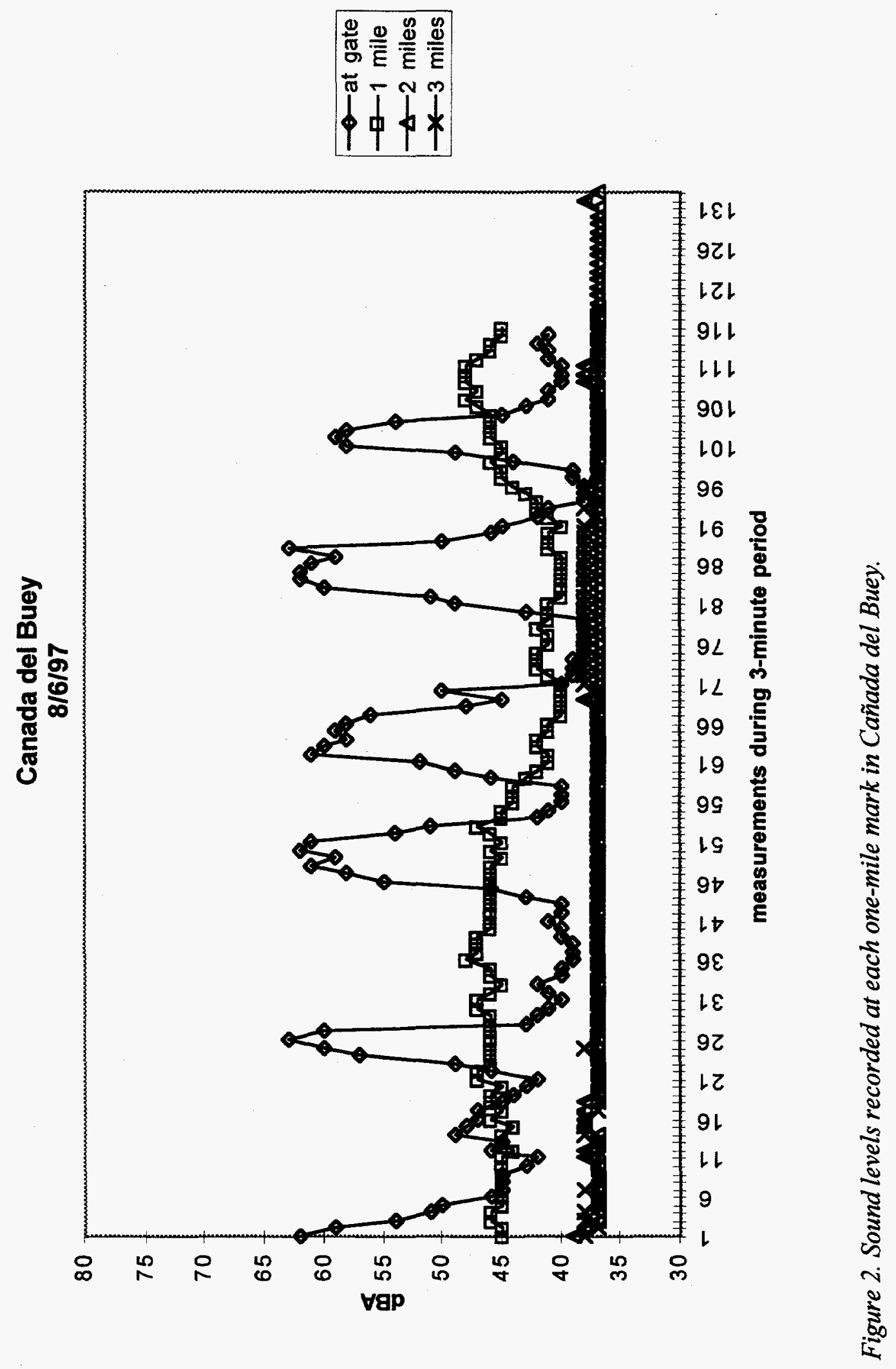




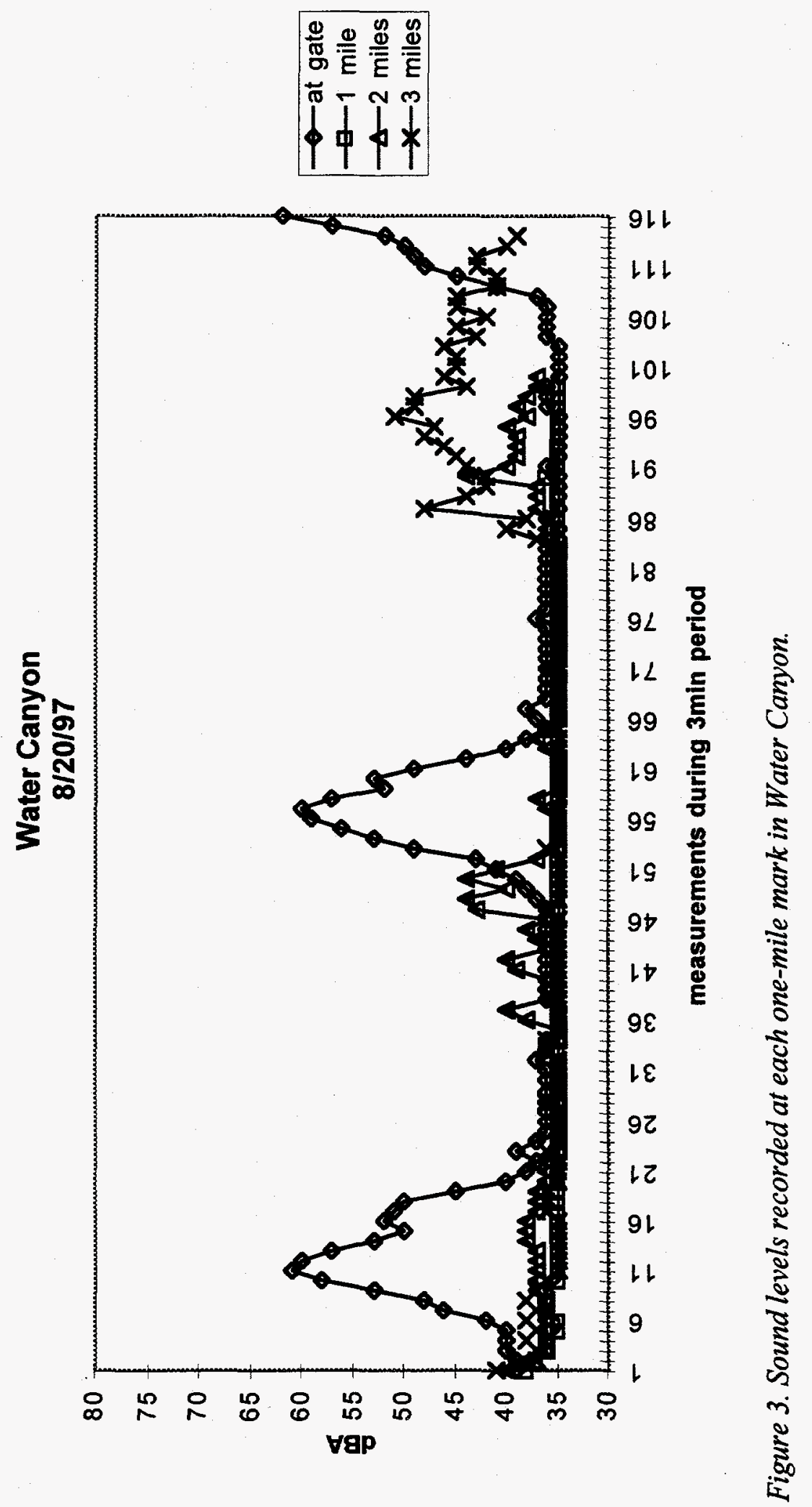




\subsection{Upper Los Alamos Canyon}

Table 6 shows the measurements from Los Alamos Canyon. Figure 6 shows the approximately 110 data points taken at each one-mile mark. At the gate of Los Alamos Canyon, the noise was due to both the stream, which was approximately 20 feet away, and the approach of a car on the road into the canyon toward the end of the measurements, the car was approximately 50 feet away at the nearest while recording was taking place.

The fairly high reading at 1 mile from the gate was caused by the almost continuous passing of joggers.

\subsection{Disturbances}

Several disturbances occurred while sound measurements were being recorded. These are all fairly routine and included thunder (one time), cars, flowing water, and joggers (Table 7). While these sounds may not seem to be extremely loud, compared to other environmental noise they are significant.

\subsubsection{Passing Cars}

Passing cars caused a large increase in the readings at several of the gates, the exact magnitude of the increase depended on the distance from the cars, the speed of the passing cars, and the number of cars passing simultaneously. Table 8 shows the noise levels for passing cars in three canyons. Figure 7 shows the data points for the threeminute measurements taken at the three canyons where cars were heard. The higher maximum, and therefore higher reading of a passing car, for Los Alamos Canyon is due to the fact that there were multiple cars passing simultaneously.
The higher average is due to the fact that the cars went by almost constantly, which did not allow for the sound level to reach its minimum point. Both Cañada del Buey and Water Canyon had practically the same maximum reading, in both cases only a single car passed at any point in time and time elapsed between each pass, allowing the meter to register the natural background noise.

\subsection{Discussion}

In Los Alamos County, animals experience sound that varies widelyfrom loud, stochastic thunderclaps, continuous traffic noises, and running water. As could be expected, sound levels were higher in areas of human disturbance-near paved roads and in canyons adjacent to developments-than in areas away from human disturbances. In order to minimize the effects of increased noise levels, future developments should be placed near areas of existing disturbance, leaving those areas that are isolated from human impacts to remain free from projects that would greatly increase the ambient noise levels.

In the future, more baseline sound levels should be recorded to make certain that the data presented above are indicative of typical noise levels.

\subsection{Acknowledgments}

This project was funded as part of the Threatened and Endangered Species Habitat Management Plan. We would like to thank Leslie Hansen, ESH20 , for assisting in the field, Teralene 
वे

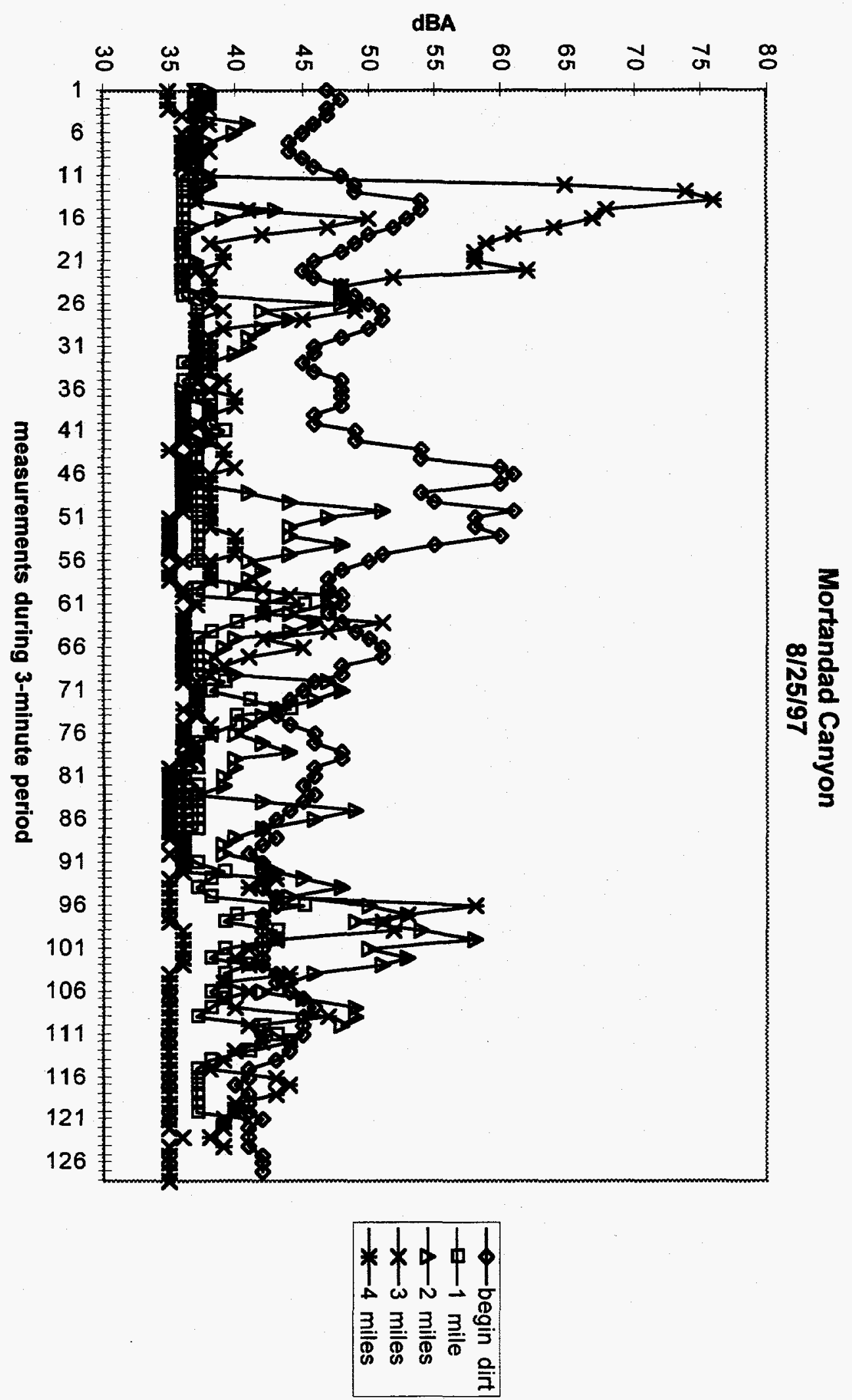



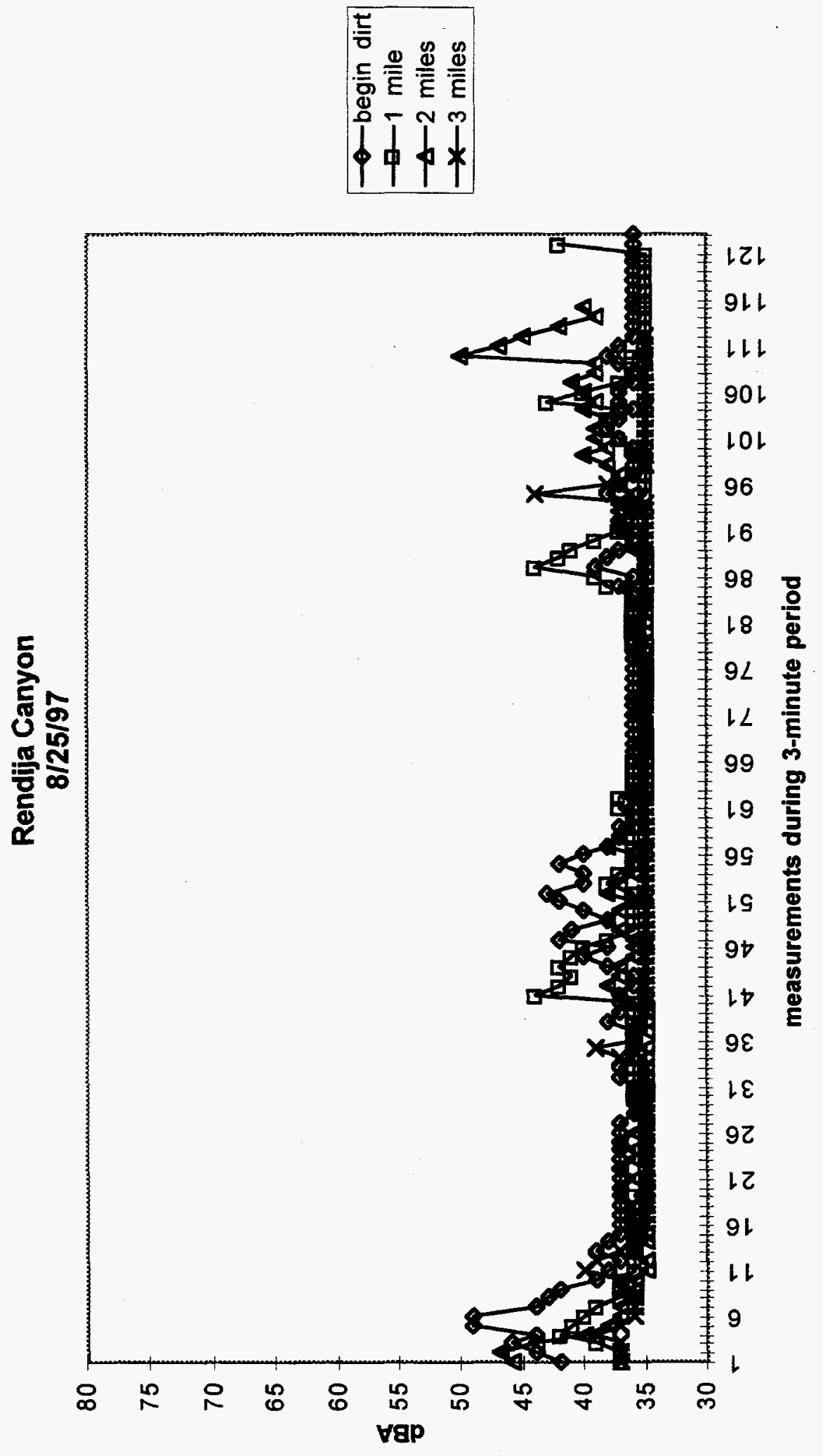

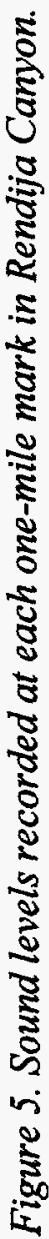




\begin{tabular}{cc|ccc}
\hline \hline \multicolumn{3}{l}{ Table 5: Measurements taken in Rendija Canyon; August 25, 1997, 3:35 to 4:05 PM. } \\
\hline $\begin{array}{c}\text { end of } \\
\text { pavement }\end{array}$ & \multicolumn{3}{c}{ miles from end of pavement } \\
\hline & $\varnothing$ & 1 & 2 & 3 \\
\hline mean (dBA) & 38 & 37 & 37 & 36 \\
\hline $\begin{array}{c}\text { maximum } \\
\text { (dBA) }\end{array}$ & 49 & 44 & 50 & 44 \\
\hline $\begin{array}{c}\text { minimum } \\
\text { (dBA) }\end{array}$ & 36 & 35 & 35 & 35 \\
\hline $\begin{array}{c}\text { standard } \\
\text { deviation }\end{array}$ & 2.6 & 2.2 & 2.8 & 1.3 \\
\hline
\end{tabular}

Table 6: Measurements taken in Upper Los Alamos Canyon;

August 25, 1997, 4:29 to 4:45 PM.

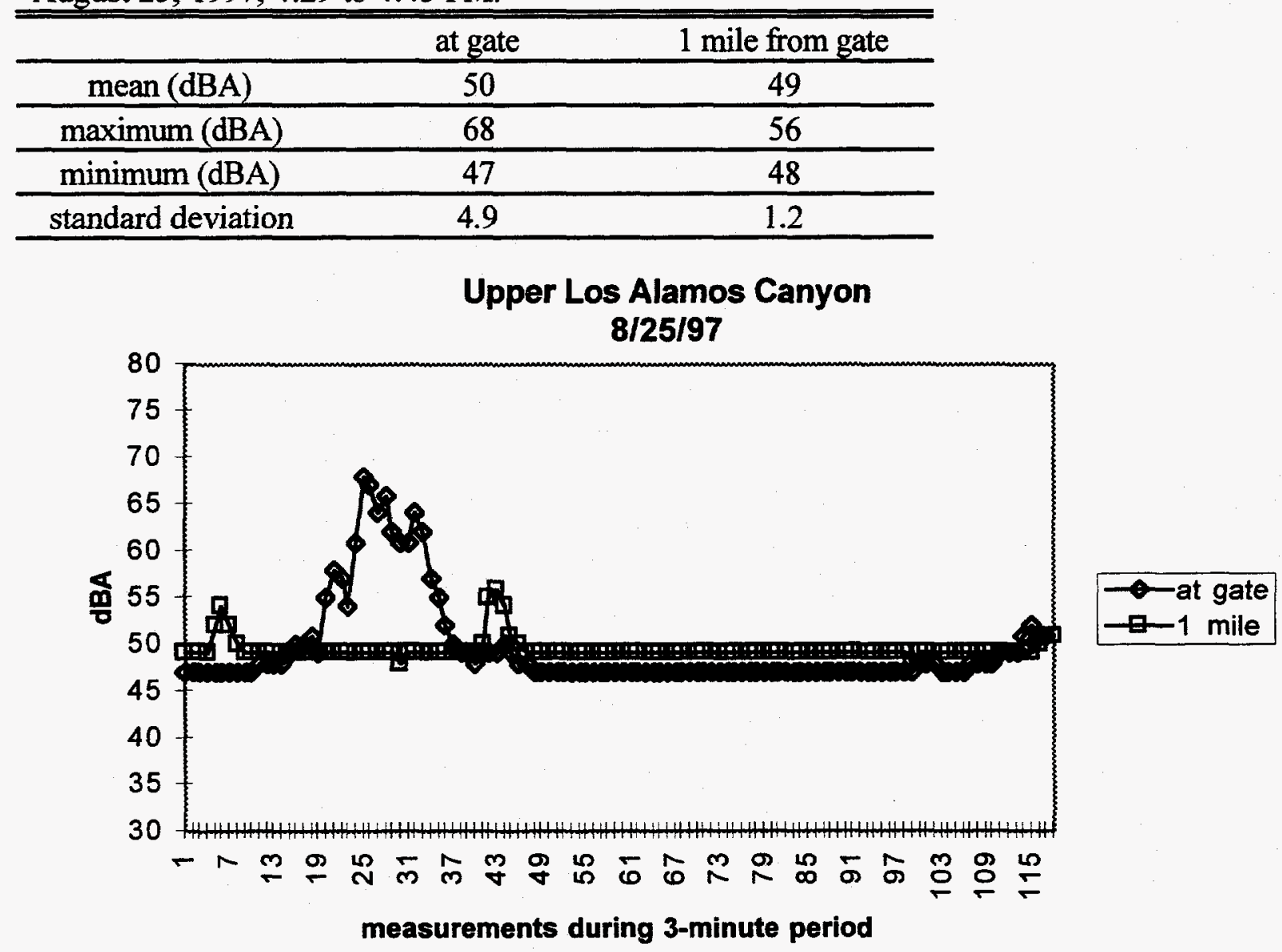

Figure 6. Sound levels recorded at each one-mile mark in Upper Los Alamos Canyon. 


\begin{tabular}{ccc}
\hline \hline Table 7: Summary of disturbances. & \\
\hline \hline & background (dBA) & $\begin{array}{c}\text { maximum value of } \\
\text { disturbance }(\mathrm{dBA})\end{array}$ \\
\hline cars & 35 & 74 \\
\hline thunder & 35 & 76 \\
\hline runners & 48 & 56 \\
\hline flowing water & 38 & 52 \\
\hline
\end{tabular}

\begin{tabular}{|c|c|c|c|}
\hline & $\begin{array}{c}\text { Los Alamos Canyon } \\
8-6-97,8: 30 \text { AM }\end{array}$ & $\begin{array}{l}\text { Cañada del Buey } \\
8-6-97,9: 56 \text { AM } \\
\end{array}$ & $\begin{array}{c}\text { Water Canyon } \\
\text { 8-20-97, 9:02 AM } \\
\end{array}$ \\
\hline maximum & 74 & 63 & 62 \\
\hline minimum & 45 & 38 & 35 \\
\hline mean & 62 & 47 & 41 \\
\hline standard deviation & 6.1 & 8.0 & 7.6 \\
\hline
\end{tabular}

cars

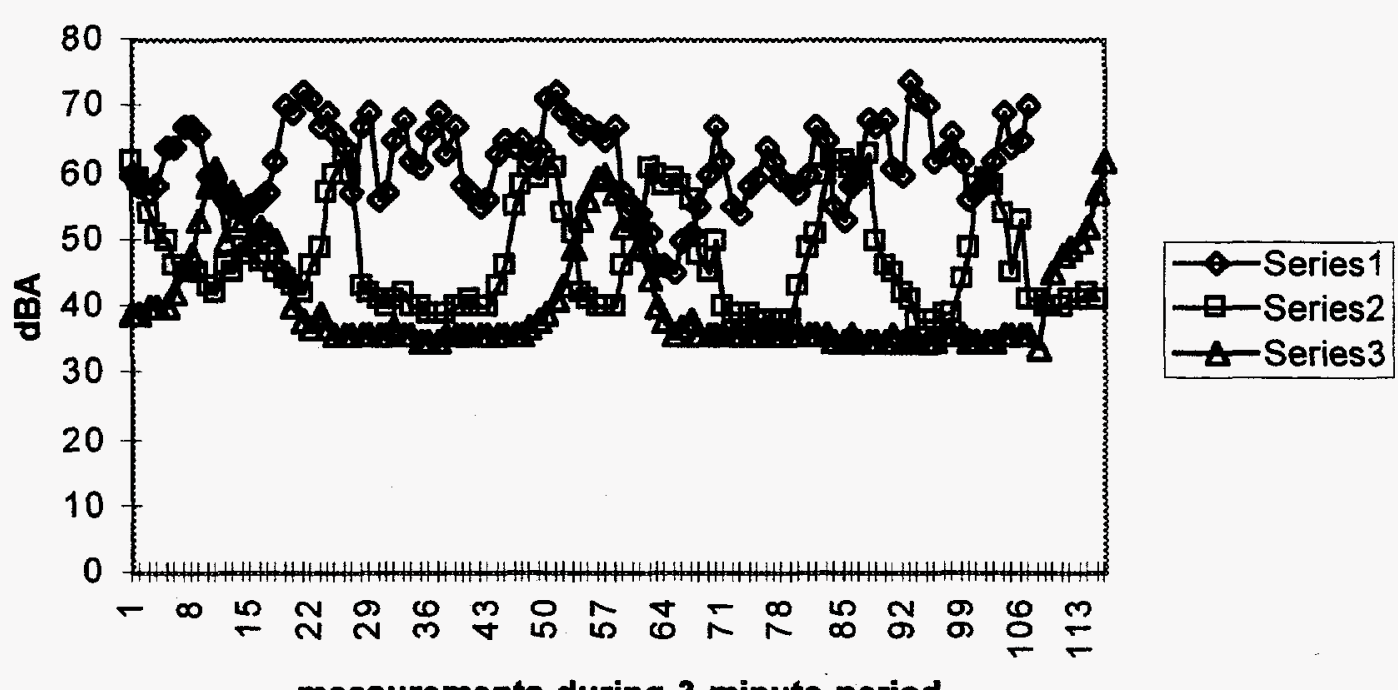

measurements during 3-minute period

Figure 7. The data points recorded at the gates of Los Alamos Canyon (Series 1), Cañada del Buey (Series 2), and Water Canyon (Series 3) during the three-minute period when cars passed by. 
Foxx, project manager, for her technical support, and Hector Hinojosa, CIC-1, for manuscript preparation.

\subsection{Literature Cited}

Awbrey, L., D. Hunsaker, and R.

Church, "Acoustical Responses of

California Gnatcathcers to Traffic

Noise," Internoise 95 971-975

(1995).

Awbrey, L., and D. Hunsaker, "Effects

of Military Aircraft Noise on

California Gnatcatchers," Biology

Department, San Diego State

University (1997).

Bell, L. H., and Associates, "Industrial

Noise Control: Fundamentals and

Applications," (Marcel Dekker, Inc., New York, 1982).

Burns, M., "White Rock Noise

Measurements During PHERMEX

Tests, 11 March 1995," Los Alamos

National Laboratory memorandum

DX-DO:DARHT-95-31 (1995).

Delaney, D., T. Grubb, and L. Pater, "Effects of Helicopter Noise on Nesting Mexican Spotted Owls," U.S. Air Force 49 CES/CEV Holloman Air Force Base Profect Order No. CE P.O. 95-4 (1997).

Ellis, D., C. Ellis, and D. Mindell,

"Raptor Responses to Low-Level Jet Aircraft and Sonic Booms,"

Environmental Pollution 74:1 53-83

(1991).

Fletcher, J., and R. G. Busnel, Effects of Noise on Wildlife, (Academic Press, New York, 1978).

Haarmann, T., T. Haagenstad, and J.

Biggs, "Biological Assessment for the Development of a Research Park on Leased Land," Los Alamos
National Laboratory report LA-UR97-3445.

Keller, D., and T. Foxx, "Biological Assessment for Threatened and Endangered Species at the DP Road Tract Land Transfer," Ecology Group internal report (1997).

Macdonell, D. "Sound Level Measurement Results from the M-60 Automatic Rifle Test Conducted on December 6, 1984," Los Alamos National Laboratory memorandum HSE-5-84-872 (1984).

RECON, "Work Plan for Effects of Noise on Passerines at MCAS/NAS Miramar N68711-94-D-1657/0018," RECON (1997).

Vigil, E., "Noise Measurement at State Road 4 and Bandelier Turn Off at State Road 4 During PHERMEX Test on March 11, 1995," Los Alamos National Laboratory memorandum ESH-5:95-11825 (1995).

Ward, D., R. Stehn, and D. Derksen, "Response of Staging Brant to Disturbance at the Izembek Lagoon, Alaska," Wildlife Society Bulletin 22 220-228 (1994). 


\section{APPENDIX 1}

Los Alamos

NATIONAL LABORATORY

memorandum

Environment, Safety and Health Division

Industrial Hygiene and Safety Group (ESH-5)
To/MS: $\quad$ Michael Burns, DX-DO (P940)

From/MS: Ernesto A. Vigil, ESH-5 (K494)

Phone/Fax: $\quad 7-0858 / 7-1945$

Symbol: ESH-5:95-11825

Date: $\quad$ March 17, 1995

\section{SUBJECT: NOISE MEASUREMENTS AT STATE ROAD 4 AND BANDELIER TURN OFF AT STATE ROAD 4 DURING PHERMEX TEST ON MARCH 11, 1995}

Sound level and octave band sound level measurements were made at two locations along State Road 4 during explosives tests at Phermex on Saturday, March 11, 1995.

The locations of these measurements were at 1) approximately $3 / 4$ mile East of TA-49 gate just inside Laboratory Property and 2) approximately 100 yards west of the bandelier turn off inside Laboratory property. GPS position measurements have been made at these locations and are as follows: $35^{\circ} 49.133^{\prime}$ LAT. $106^{\circ} 18.518^{\prime}$ LONG. and $35^{\circ} 47.797^{\prime}$ LAT. $106^{\circ} 16.545^{\prime}$ LONG. for these locations, respectively.

Measurements were made using an IVIE sound level meter at each location. The two instruments were calibrated pre-shot and post-shot. The following table presents data obtained. All readings were obtained with the wind screen in place.

Location I 3/4 Mile East of TA-49 Gate

\begin{tabular}{|c|c|c|c|c|c|c|c|c|c|c|}
\hline Shot \# & 31.5 & 63 & 125 & 250 & 500 & $1 \mathrm{~K}$ & $2 \mathrm{~K}$ & $4 K$ & $8 \mathrm{~K}$ & $\mathrm{dBA}$ \\
\hline $1(0942)$ & 32 & 42 & 54 & 52 & 50 & 46 & 42 & 44 & 48 & $\ldots$ \\
\hline $2(0943)$ & $<46$ & 52 & 58 & 58 & 46 & 52 & $<46$ & --- & 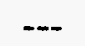 & 66.3 \\
\hline $3(0944)$ & 48 & 52 & 62 & 62 & 60 & 58 & 48 & $\cdots$ & $-\cdots$ & 68.4 \\
\hline $4(0945)$ & -- & 54 & 56 & 54 & 54 & 50 & 48 & -- & --- & 64.4 \\
\hline $5(0946)$ & 48 & 50 & 60 & 64 & 62 & 60 & 50 & 50 & -- & 70.0 \\
\hline $6(0958)$ & --- & 62 & 68 & 64 & 64 & 58 & 54 & 48 & $\cdots$ & 71.1 \\
\hline \multicolumn{11}{|c|}{ Background } \\
\hline & 31.5 & 63 & 125 & 250 & 500 & $1 \mathrm{~K}$ & $2 \mathrm{~K}$ & $4 K$ & $8 \mathrm{~K}$ & $\mathrm{dBA}$ \\
\hline & 49 & 41 & 34 & 30 & 31 & 25 & 25 & -- & $-\ldots$ & 31 \\
\hline \multicolumn{11}{|c|}{ IVIE \#677 } \\
\hline \multirow{2}{*}{\multicolumn{11}{|c|}{$\begin{array}{l}\text { Location II } \\
\text { Yards West o }\end{array}$}} \\
\hline & & & & $100 Y$ & $s$ Wes & Banc & $\mathrm{r}$ Ent & & & \\
\hline Shot \# & 31.5 & 63 & 125 & 250 & 500 & $1 \mathrm{~K}$ & $2 \mathrm{~K}$ & $4 K$ & $8 \mathrm{~K}$ & $\mathrm{dBA}$ \\
\hline $1(942)$ & $<50$ & $<50$ & $<50$ & $<50$ & $<50$ & $<50$ & $<50$ & $<50$ & -- & 63 \\
\hline $2(943)$ & \multicolumn{10}{|c|}{ Data made invalid by Road Noise } \\
\hline $3(944)$ & 38 & 52 & 56 & 54 & 52 & 48 & 42 & 40 & 36 & --- \\
\hline $4(945)$ & 36 & 42 & 50 & 50 & 54 & 56 & 48 & 40 & 42 & 62 \\
\hline $5(946)$ & 40 & 46 & 54 & 52 & 48 & 42 & 38 & 36 & 40 & 61 \\
\hline $6(958)$ & 40 & 48 & 54 & 56 & 52 & 54 & 52 & 36 & $<36$ & 60 \\
\hline
\end{tabular}


$-2-$

$\begin{array}{cccccccccc}8 & \text { Background } \\ 31.5 & 63 & 125 & 250 & 500 & 1 \mathrm{~K} & 2 \mathrm{~K} & 4 \mathrm{~K} & 8 \mathrm{~K} & \text { dBA } \\ 42 & 40 & 38 & 34 & 32 & 30 & 28 & 30 & 28 & 35\end{array}$

For location number 2 the noise associated with passing traffic ranged from 60 to $64 \mathrm{dBA}$ depending on whether the individual vehicle turned off to Bandelier or continued on through, respectively.

Attachment I through III are summaries of weather data obtained at the Laboratory weather station (Bandelier [2146 MSL]) located off state road 4 southeast of TA-49.

EAV:ns

Att: Graph

Cy: IHFSS Files, ESH-5 (K494) 
Los Alamos

NATIONAL LABORATORY

memorandum

DUAL-AXIS RADIOGRAPHIC HYDROTE

FACILITY (DARHT)

DX/DO
To/MS: Distribution

From/MS: M. J. Burns, DX/DO, MS P?

Phone/Fax: $\quad$ 5-2215/7-8316

Symbol: DX/DO:DARHT-95-31

Date: $\quad$ March 13, 1995

\section{SUBJECT: WHITE ROCK NOISE MEASUREMENTS DURING PHERMEX TESTS, MARCH 11, 1995}

Reported here are sound level measurements made in White Rock by David Broxton (EES-1) and Carol Burns (ET) during PHERMEX explosives tests conducted Saturday, March 11, 1995.

The location of the measurement was approximately $100-150$ feet east of the intersection of State Road 4 and Karen Circle in White Rock. Two GPS position measurements were made at the recording location using a Garmin GPS 40 (serial number 34011915). The first result was North 35.82033 deg., West $106.22203 \mathrm{deg}$. The second reading was North $35.82019 \mathrm{deg}$., West $106.22160 \mathrm{deg}$. (W. Hawkins reports that the GPS reading at the PHERMEX firing point during instrument implacement was North $35 \mathrm{deg} ., 49.990 \mathrm{~min}$., West $106 \mathrm{deg} ., 17.682 \mathrm{~min}$.

Sound levels were recorded using a GenRad 1982 Precision Sound Level Meter and Analyzer (serial number 4420, H-5 FSS No. 170, Los Alamos property number 694063, DOE/LASL PN 347883, last calibrated Jan. 1995). Instrument settings were: Octave Filter Frequency: $250 \mathrm{~Hz}$; Weighting: A; dB Range: $30-80$; Detector: slow. A wind protector was fitted over the sensing element during the measurements.

To make the measurements, the general background level before the PHERMEX shot was recorded using the instrument's analog gauge. This background ranged from a low of about 38 $\mathrm{dBA}$ for a quiet neighborhood to a high of about $51 \mathrm{dBA}$, usually associated with a car passing on State Road 4. Radio communication was maintained with R310 and the time interval between the shot execution (provided by a countdown heard over the radio) and arrival of the blast sound was recorded (see the "Interval (sec.)" column in the table below). Finally, the peak noise level was recorded as the blast sound arrived using the instrument's digital peak hold readout. The data are presented in the table below:

\section{White Rock Sound Measurements from PHERMEX Tests 11 March 1995}

$\begin{array}{ccccc}\text { Shot Number } & \begin{array}{c}\text { Approx. HE load } \\ \text { (lbs. TNT) }\end{array} & \begin{array}{c}\text { Approx. shot } \\ \text { time (MST) }\end{array} & \begin{array}{c}\text { Peak noise level } \\ \text { (dBA) }\end{array} & \text { Interval (sec.) } \\ 0942 & 10 & 1216 & 60.9 & 19.8 \\ 0943 & 25 & 1239 & 65.3 & 19.5 \\ 0944 & 50 & 1302 & 69.1 & 19.8 \\ 0945 & 50 & 1333 & 63.1 & 19.6 \\ 0946 & 100 & 1355 & 71.6 & 19.7 \\ 0958 & 150 & 1417 & 68.6 & 20.0\end{array}$




\section{Appendix 3. Los Alamos Canyon Automatic Rifle Tests, December 6, 1984}

Sound level measurement location

State Road 4 and Los Alamos Canyon

Top of Tsankawi Mesa

Los Alamos Canyon rim near East Gate

East end of TA-53; last work area near settling pond

Los Alamos Canyon, 150 yds west of county line

$$
\begin{aligned}
& \text { Sound level } \\
& 1^{b} \\
& 1 \text { rifle }
\end{aligned}
$$

dBA bkgd.
dBA
dBC bkgd.
dBC

\section{dBA bkgd. dBA} dBC bkgd. $\mathrm{dBC}$

42
44
52
54

42
46
52
56

dBA bkgd. dBA dBC bkgd. $\mathrm{dBC}$

$\begin{array}{cc}50 & 50 \\ A, B & A, B \\ 60 & 60\end{array}$

$$
\begin{gathered}
42 \\
\mathrm{~A}
\end{gathered}
$$$$
\begin{array}{r}
\text { A } \\
60
\end{array}
$$$$
62
$$$$
\begin{gathered}
42 \\
\mathrm{~A} \\
60 \\
62
\end{gathered}
$$

55
$\mathrm{~A}, \mathrm{C}$
65

$\begin{array}{cc}55 & 63 \\ \mathrm{~A}, \mathrm{C} & \mathrm{A}, \mathrm{D} \\ 65 & \mathrm{E}\end{array}$

42
49
57
59
63
A, D
E
E

42
52
57
61
63
A, D
E
E

$\begin{array}{ll}40 & 40 \\ 64 & 64 \\ 50 & 50 \\ 69 & 72\end{array}$

63

62

68
E, F
62

$\mathrm{E}, \mathrm{F}$

$65 \quad 65$

A, F A, F$$
1 \text { rifle } 2 \text { rifles }
$$

$\begin{array}{cc}58 & 58 \\ 64, \mathrm{~B} & 66, \mathrm{~B} \\ \mathrm{E} & \mathrm{E} \\ \mathrm{E} & \mathrm{E}\end{array}$

$\begin{array}{cc}62 & 62 \\ 62 & 68 \\ 67 & 68 \\ \mathrm{E} & \mathrm{E}\end{array}$

dBA bkgd.

$\begin{array}{cc}\text { dBA } & 65 \\ \text { dBC bkgd. } & 49 \\ \text { dBC } & 71 \\ \text { dBA bkgd. } & 36 \\ \text { dBA } & 76 \\ \text { dBC bkgd. } & 48 \\ \text { dBC } & 81\end{array}$

$\begin{array}{ccc}34 & 34 & 34 \\ 68 & 57 & 62 \\ 49 & 49 & 49 \\ 72 & 71 & \text { E } \\ 36 & 37 & 37 \\ 80 & 57 & 58 \\ 48 & 50 & 50 \\ 90 & 64 & 65\end{array}$

$\begin{array}{ccc}63 & 63 & 63 \\ 68 & 68 & 68 \\ 68 & 68 & 68 \\ \text { E } & \text { A, F } & \text { A, F } \\ 34 & \text { E } & \text { E } \\ & & \\ 66 & \text { E } & \text { E } \\ 49 & \text { E } & \text { E } \\ 70 & \text { E } & \text { E } \\ 37 & 37 & 38 \\ 70 & 61 & 66 \\ 50 & 48 & 48 \\ 74 & 70 & 72\end{array}$

(a.) $\mathrm{dBA}$ and $\mathrm{dBC}$ sound levels, reference $20 \mu \mathrm{Pa}$. (b.) Firing location 1, 20 yards east of thecounty line. (c.) Firing location 2, about 100 yards up unnamed side canyon, approximately 700 yards east of the county line. (d.) Firing location 3, north of side canyon, approximately 700 yards east of the county line. (e.) Firing location 4 , approximately 1400 yards east of the county line, approximately 1400 yards from Los Alamos Canyon entrance at State Road 4. (f.) Background is the ambient sound level in the area surrounding the measurement location with no test in progress.
(A.) No reading above background, masked by traffic noise.
(B.) Observed irregular traffic noise.
(C.) Increasing traffic noise.
(D.) Barely distinguishable as a low roar.
(E.) No measurement made. (F.) Constant heavy traffic. 


\section{Appendix 4}

\begin{tabular}{ccc|cccc}
\hline \multicolumn{6}{c}{ Sound level measurements from a truck horn at increasing distances } \\
east to west along the mesa top.
\end{tabular}

\begin{tabular}{|c|c|c|c|c|c|c|}
\hline \multicolumn{7}{|c|}{$\begin{array}{l}\text { Sound level measurements of a truck horn from the north rim of Los Alamos Canyon } \\
\text { following a transect going beyond the cliff on the north-facing slope containing the } \\
\text { potential nest site down to the canyon bottom and up toward the south rim. }\end{array}$} \\
\hline Location & $\begin{array}{l}\text { Background } \\
\text { (dBC) }\end{array}$ & $\begin{array}{l}\text { Background } \\
\text { (dBA) }\end{array}$ & $\begin{array}{l}\text { Source } \\
\text { Sound } \\
\text { (dBC) }\end{array}$ & $\begin{array}{l}\text { Source } \\
\text { Sound } \\
\text { (dBA) }\end{array}$ & $\begin{array}{l}\text { dB over } \\
\text { Background } \\
\text { (dBC) }\end{array}$ & $\begin{array}{c}\text { dB over } \\
\text { Background } \\
\text { (dBA) }\end{array}$ \\
\hline $\begin{array}{l}\text { at source } \\
\text { on rim }\end{array}$ & 65.3 & 61.1 & 117.3 & 121.5 & 52 & 60.4 \\
\hline $\begin{array}{c}25 \mathrm{~m} \\
\text { (at shelf) }\end{array}$ & 65.4 & 60.3 & 74.5 & 62.3 & 9.1 & 2 \\
\hline $\begin{array}{c}50 \mathrm{~m} \\
(1 / 2 \text { way } \\
\text { down) } \\
\end{array}$ & 65.3 & 60.1 & 63.2 & 60.9 & $\begin{array}{c}\text { below } \\
\text { background }\end{array}$ & 0.9 \\
\hline $\begin{array}{c}140 \mathrm{~m} \\
\text { (at stream) }\end{array}$ & 60.9 & 62.3 & 72.3 & 68.5 & 11.4 & 6.2 \\
\hline $\begin{array}{c}155 \mathrm{~m} \\
\text { (at road) }\end{array}$ & 60.9 & 62.3 & 64.3 & 61.9 & 4 & $\begin{array}{c}\text { below } \\
\text { background }\end{array}$ \\
\hline $\begin{array}{c}200 \mathrm{~m} \\
\text { (cliff face) }\end{array}$ & 60.2 & 61.6 & 59.8 & 60.5 & $\begin{array}{c}\text { below } \\
\text { background }\end{array}$ & $\begin{array}{c}\text { below } \\
\text { background }\end{array}$ \\
\hline $\begin{array}{c}220 \mathrm{~m} \\
\text { (near } \\
\text { south rim) }\end{array}$ & 60.3 & 61.3 & 60.2 & 60.8 & & \\
\hline
\end{tabular}




\section{Appendix 5.}

\begin{tabular}{|c|c|c|}
\hline \multicolumn{3}{|c|}{$\begin{array}{l}\text { Noise measurements of a car horn at an increasing distance from the source in an } \\
\text { area north of West Jemez Road. }\end{array}$} \\
\hline Point & Level (dBC) & Background (dBC) \\
\hline (source) & 113 & 70 \\
\hline $50 \mathrm{~m}$ & 66 & 62 \\
\hline $100 \mathrm{~m}$ & 66 & 62 \\
\hline $150 \mathrm{~m}$ & 62 & 64 \\
\hline $200 \mathrm{~m}$ & 66 & 60 \\
\hline
\end{tabular}

